\title{
The Characteristic Features of Our Cases With Diagnosis of Pulmonary Septic Embolism
}

\author{
Coşkun Doğan, Sevda Şener Cömert, Benan Çağlayan, \\ Elif Torun Parmaksız, Ali Fidan, Nesrin Kıral, Banu Salepçi
}

Department of Chest Diseases, Kartal Dr. Lütfi Kırdar Training and Research Hospital, İstanbul, Turkey

Submitted: 07.05.2016 Accepted: 08.08.2016

Correspondence: Coşkun Doğan, Kafkas Üniversitesi Tıp Fakültesi, Göğüs Hastalıkları Anabilim Dalı, Kars, Turkey

E-mail: coskund24@yahoo.com

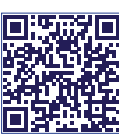

Keywords: Pulmonary embolism; septic pulmonary embolism; tooth extraction.

\begin{abstract}
Objective: The aim of the present study was to investigate the clinical, radiological and laboratory features of septic pulmonary embolism (SPE), a rare disease with high morbidity and mortality rates.
\end{abstract}

Methods: Files of patients with final diagnosis of SPE who underwent examinations and treatments based on initial diagnosis of SPE between January 20II and December 2015 were examined retrospectively. Demographic, clinical, radiological, and laboratory findings of these patients were recorded.

Results: Total of 10 patients, 3 female and 7 male, with mean age of $44.4 \pm 9.8$ years were included in the study. Most frequently detected primary infection focus was site of extraction of abscessed tooth, seen in 4 (40\%) cases. Most common presenting symptom was chest pain, observed in 9 (90\%) patients, and most common radiological finding was bilateral parenchymal nodules, seen in $8(80 \%)$ patients. All patients gave complete clinical and radiological response to antibiotic therapy; there was no incidence of exitus.

Conclusion: SPE should be included in differential diagnosis of patients with radiologically detected bilateral nodules, if infection parameters are also at high levels. Primary focus of infection should be investigated and administration of appropriate antibiotics should be initiated.

\section{INTRODUCTION}

Septic pulmonary embolism (SPE) is a rarely seen infectious disease of the lungs. Since it lacks specific clinical symptoms of its own, diagnosis can prove difficult. Nonspecific clinical findings are evaluated with radiological signs, and if potential spread of disease from a primary focus of infection is kept in mind, then difficulties encountered during diagnostic process can be overcome. Fundamental pathogenesis of SPE involves entry of fibrins containing microorganisms from the focus of primary infection into circulation through hematogenous route, leading to formation of nodular or cavitary lesions at terminal regions of vessels of pulmonary parenchyma by way of pulmonary arteries. Generally, it manifests itself with nonspecific symptoms, such as fever, chest pain, coughing, or hemoptysis, and suggestion of infectious disease. Radiologically, on peripheral pulmonary areas adjacent to vascular regions, multiple, bilateral nodules and/or cavities are seen. Pulmonary artery leading directly to lesion is known as "feeding vessel sign.” ${ }^{[1-5]}$

Multiple, bilateral nodules and/or cavitary lesions, seen most often on peripheral areas of anteroposterior (AP) chest radiograms, in combination with clinical signs suggesting SPE are usually enough to make diagnosis. However, computed tomography (CT) is superior imaging modality, particularly in demonstra- 
tion of feeding vessel sign and relationship between pleural cavity and lesions. Differential diagnosis of SPE is challenging. Radiologically and clinically, cases closely resemble pulmonary malignancies, pulmonary metastases of extrapulmonary malignancies, and tuberculosis; SPE should also be kept in mind in such cases. To establish diagnosis of SPE, focus (foci) of infection must be determined. Most important prognostic factor is early diagnosis, followed by early initiation of suitable broad-spectrum antibiotherapy. ${ }^{[5-7]}$ Early diagnosis of SPE can avoid invasive examinations and deterioration of condition.

Present study was an investigation of clinical, radiological, and biochemical characteristics of SPE, which occasionally presents diagnostic difficulties.

\section{PATIENTS AND METHODS}

Archives of the clinic of the department of chest diseases of Kartal Dr. Lütfi Kırdar Training and Research Hospital were screened. Files of cases examined and treated on either ambulatory or inpatient basis with initial diagnosis of SPE between January $201 \mathrm{I}$ and December 2015 were reviewed retrospectively. Demographic information of patient age, gender, comorbidities, and smoking status were recorded. Complaints at admission, data from physical examination, radiological tests (AP chest $\mathrm{X}$-ray and thoracic $C T$ ), biochemical and microbiological tests, length of hospital stay, antibiotherapy used, and cause of SPE were recorded and analyzed.

\section{RESULTS}

Total of 15 ambulatory cases or patients hospitalized between January $201 \mathrm{I}$ and December 2015 with initial diagnosis of SPE were examined. Cases with final diagnosis of malignancy metastasized to the lungs $(n=3)$ and tuberculosis $(n=2)$ were excluded, and remaining 10 patients were included in the study.

Study population consisted of 3 (30\%) female and 7 (70\%) male patients with overall mean age of $44.4 \pm 9.8$ years. Comorbidities were detected in only $4(40 \%)$ patients. Most frequent comorbidities were chronic heart and vascular diseases. Most commonly detected symptom and examination findings were chest pain $(n=9 ; 90 \%)$ and bilateral rales $(n=3 ; 30 \%)$. High fever was detected at admission in $6(60 \%)$ cases, and mean body temperature was $37.8 \pm 1.2^{\circ} \mathrm{C}$. Radiological evaluation of AP chest radiograms reve-

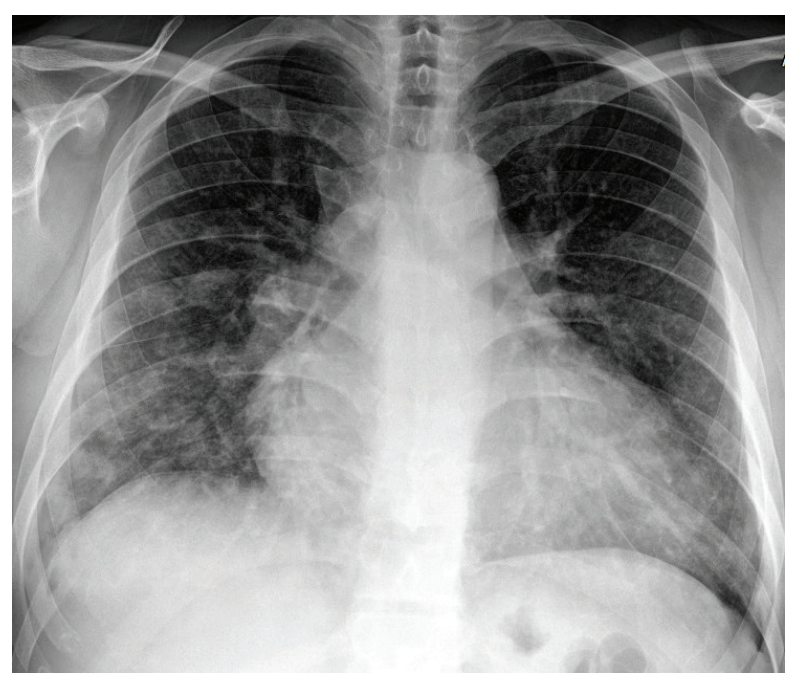

Figure 1. Bilateral nodular images on chest X-ray of the case diagnosed as septic pulmonary embolism.

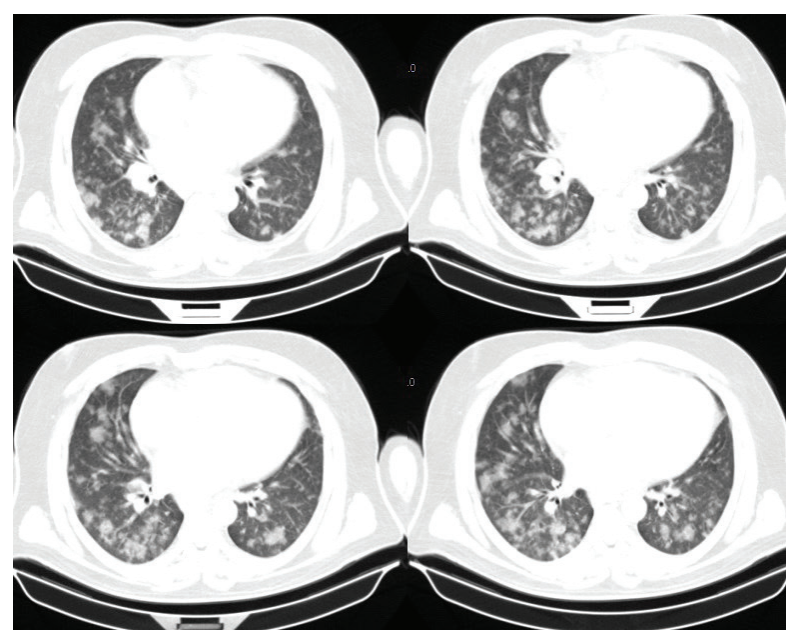

Figure 2. Bilateral multiple nodular, occasionally cavitary images on computed tomograms of the case diagnosed as septic pulmonary embolism.

aled bilateral involvement. Bilateral nodules appeared most frequently and were seen in $6(60 \%)$ cases (Figure I). Thoracic CT also indicated bilateral involvement in all (100\%) cases (Figure 2). Mean \pm SD values of some laboratory parameters were as follows: white blood cell count (WBC): I7| $57 \pm$ | | 577.8/uL, sedimentation rate: $67 \pm 30 \mathrm{~mm} / \mathrm{hr}$, and serum C-reactive protein (CRP): $127.3 \pm$ I $17.8 \mathrm{mg} / \mathrm{L}$. Detailed clinical, radiological, and demographic data of cases included in the study are provided in Table I.

Antibiotherapy was initiated in all cases. As initial antibiotherapy, third-generation cephalosporin (cephtriaxone; $n=4$ ), third-generation cephalosporin 


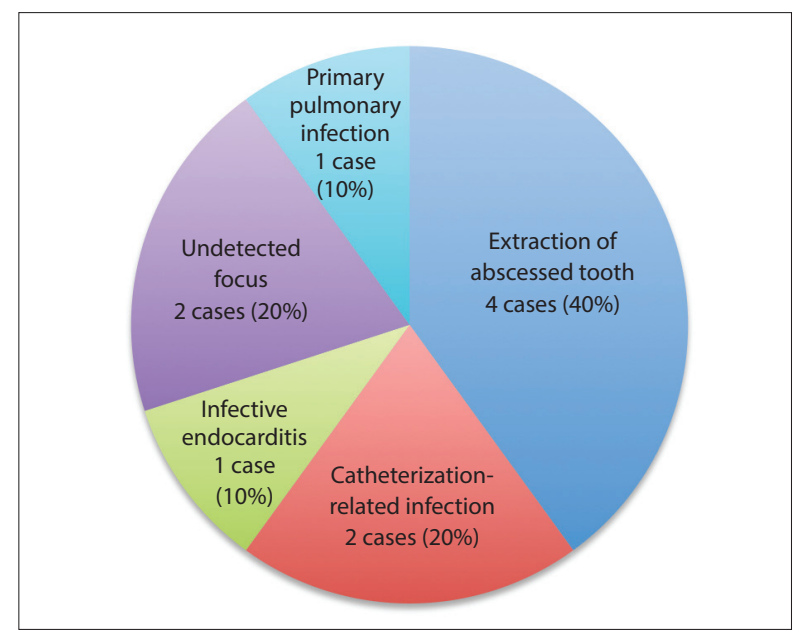

Figure 3. Primary infection foci detected in the cases.

plus oral macrolide (clarithromycin; $n=4$ ), or secondgeneration cephalosporin (cefuroxime axetil) plus clarithromycin $(n=2)$ were administered. In I case, Staphylococcus hominis grew on culture media, and antibiotherapy with intravenous (IV) meropenem and linelozid was provided. Antibiotherapy with cephtriaxone and daptomycin was used for I patient whose antibiogram revealed growth of methicillinresistant coagulase-negative Staphylococcus aureus. Patients were treated as outpatients $(n=3 ; 30 \%)$ or inpatients $(n=7 ; 70 \%)$. Inpatients were hospitalized for mean period of $8.1 \pm 3$.I days. Most frequently detected primary focus of infection was related to extraction of abscessed tooth, seen in $4(40 \%)$ cases. Foci of primary infection are provided in Figure 3.

\section{DISCUSSION}

The present study was designed to investigate clinical and radiological features of SPE. Medical files of 10 ambulatory or inpatient cases with final diagnosis of SPE made in our department were analyzed. Based on study findings, it was concluded that SPE should be included in differential diagnosis when bilateral nodular or cavitary images in the lungs, presence of primary focus (foci) of infection, and parameters of infection, such as high fever and sedimentation rate are evaluated.

SPE is a rarely seen disease with a severe course. IV drug use; infective endocarditis; septic thrombophlebitis; suppurative angina; periodontal disease, such as dental abscess; purulent infections of soft tissue; hemodialysis; and intravascular catheterizati-
Table 1. Clinical, radiological, and demographic findings of the cases

\begin{tabular}{lcc}
\hline & $\begin{array}{c}\text { Cases } \\
(\mathrm{n}=10)\end{array}$ & $\%$ \\
\hline Age, years (Mean \pm SD) & $44.4 \pm 9.8$ & - \\
Gender ( $\mathrm{n})$ & & \\
$\quad$ Female & 3 & 30 \\
$\quad$ Male & 7 & 70 \\
Smoking (packs-year, mean \pm SD) & $11.2 \pm 10.2$ & - \\
Comorbid diseases & & \\
$\quad$ Absent & 6 & 60 \\
$\quad$ Present & 4 & 40 \\
Symptoms & & \\
$\quad$ Chest pain & 9 & 90 \\
$\quad$ Fever & 5 & 50 \\
$\quad$ Coughing & 4 & 40 \\
Sputum & 1 & 10 \\
Dyspnea & 1 & 10 \\
Hemoptysis & 1 & 10 \\
Other & 2 & 20
\end{tabular}

Physical examination

Bilateral rales

6

60

Unilateral rales

$\mathrm{RR}$ (mean/min)

$3 \quad 30$

$\mathrm{MHR}$ (mean $\pm \mathrm{SD} / \mathrm{min})$

$1-10$

$\mathrm{CPR}($ mean $\pm \mathrm{SD} / \mathrm{mmHg})$

$19.9 \pm 4$

DAP (mean \pm SD)/mmHg)

$81.8 \pm 10.2$

$127.3 \pm 15.4$

Body temperature

(mean $\pm \mathrm{SD} /{ }^{\circ} \mathrm{C}$ )

$76.4 \pm 7.3$

$37.8 \pm 1.2$

AP chest X-ray

Bilateral involvement $\quad 6 \quad 60$

Unilateral involvement $\quad 4 \quad 40$

$\begin{array}{lll}\text { Consolidation } & 2 & 20\end{array}$

$\begin{array}{lll}\text { Nodule } & 6 & 60\end{array}$

Cavitary nodule $\quad 2 \quad 20$

Thoracic CT

Bilateral involvement $\quad 10 \quad 100$

$\begin{array}{lll}\text { Bilateral nodules } & 8 & 80\end{array}$

Bilateral cavitary nodules $\quad 2 \quad 20$

$\begin{array}{lll}\text { Feeding vessel sign } & 6 & 60\end{array}$

CT: Computed tomography; RR: Respiratory rate per minute; DAP: Diastolic arterial pressure; MHR: Maximum heart rate; AP: Anteroposterior; SAP: Systolic arterial pressure; SPE: Septic pulmonary embolism.

on are among frequent causes of the disease. Literature review disclosed that SPE was more frequently seen during 1970s in association with IV drug use; 


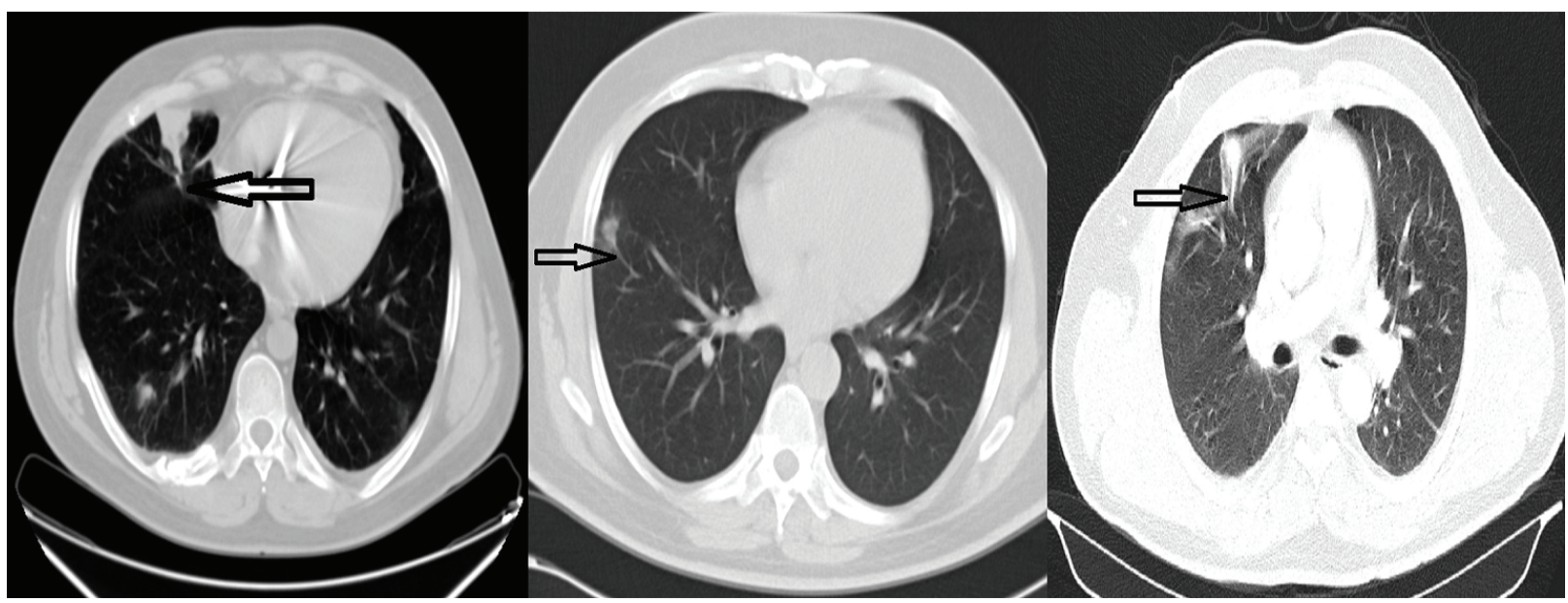

Figure 4. Feeding vessel sign (black arrow) observed on thoracic computed tomograms of three distinct cases.

subsequently, it was more often reported in relation to intravascular catheterization used for cancer chemotherapy or parenteral nutritional support. ${ }^{[8]}$ In the present study, primary foci of infection in order of decreasing frequency were tooth abscess in $40 \%$ of cases, catheter-related infection in $20 \%$, and infective endocarditis in $10 \%$.

There is no definitive clinical finding that will definitively determine presence of SPE. Clinical findings are nonspecific and mostly suggest infectious disease. When clinical and radiological characteristics are viewed in combination, primary focus of infection may come to mind. Patients frequently present with fever, shortness of breath, chest pain, coughing or sputum, and rarely, hemoptysis. ${ }^{[8-10]}$ In our series, most frequent presenting symptom was chest pain, observed in $90 \%$ of the cases. Most probable cause of chest pain is focus of infection localized in peripheral regions of pulmonary parenchyma, which interface with the pleura.

During the diagnostic process, typically AP pulmonary radiograms are obtained first. Although visualization of bilateral, or occasionally cavitary nodules, is critical tool, these signs are not sufficient to make final diagnosis of SPE. Thoracic CT is more specific imaging modality than AP chest $X$-ray. In a study performed by Iwasaki et al., ${ }^{\left[{ }^{\prime \prime}\right]}$ all lesions specific to SPE were visualized on thoracic CT, including bilateral, multiple, peripheral cavitary and non-cavitary lesions, while wedge-shaped infiltrations were visible on AP pulmonary radiograms in only $68 \%$ of cases. This finding supports higher sensitivity of thoracic CT relative to AP pulmonary radiograms. In our study, only $60 \%$ of bilateral nodules were visualized on AP pulmonary radiograms, while all (100\%) were seen on thoracic CT.

In most studies, feeding vessel sign has been reported as the most frequently seen specific radiological finding in diagnosis of SPE. The sign demonstrates presence of pulmonary artery leading to peripheral lesion and signifies hematogenous origin of nodule in pulmonary parenchyma. This sign is also seen in cases of metastases of extrapulmonary malignancy or embolism of thrombotic origin. ${ }^{[12,13]}$ Feeding vessel sign was detected in $60 \%$ of cases in present study (Figure 4).

Onset of SPE is result of settlement of material containing infected fibrin in pulmonary parenchyma via pulmonary arteries. Since it is an infectious disease, hints of infection are always present and should be investigated. Parameters of infection at time of presentation, such as high fever, increased CRP and WBC levels and sedimentation rate, seen in patients with compatible radiological images and risk factors should be considered for SPE. ${ }^{[14]}$ All parameters of infection were high in present study patients.

Sputum and blood samples were sent for antibiotic susceptibility tests in all cases, and bacterial growth was observed on 3 blood cultures. Empirical antibiotherapy was initiated for all patients, and adjusted as needed for those with positive results for bacterial growth. All patients responded to antibiotherapy from both clinical and radiological perspectives. During first weeks of treatment, decrease in fever, sedimentation rate, and CRP levels were observed, and on first week follow-up AP pulmonary radiograms, 
pathological signs had regressed markedly. In a largescale review study conducted by Ye et al., ${ }^{[15]} 76$ articles and 168 case reports were reviewed, and 122 cases with treatment regimen were examined. It was reported that most frequently $(n=38)$ initiated empirical antibiotherapies were penicillins and cephalosporins. Based on results of this large-scale review, authors emphasized necessity of early diagnosis and treatment. In that series, I5 of 168 (8.9\%) patients died as result of various causes, predominantly septic shock. In present series, all of the patients survived. Similarly to review study, most frequently used initial antibiotherapy of present study was cephalosporin; however, in contrast to literature findings, remarkably higher number of our patients were started on oral macrolide therapy. Many factors had a role in our choice of antibiotherapy regimen. A priori, we assumed our patients to have pneumonia, and initiated treatment accordingly. Secondly, we didn't discontinue initial antibiotherapy, so as not to cause deterioration of clinical status of the patients who displayed rapid clinical improvement. Finally, we do not have a national guideline concerning treatment of SPE.

The greatest limitation of our study is its retrospective design, and therefore, different diagnostic, and therapeutic modalities could have been tried in each case. Although SPE is spread via hematogenous route, small number of cases had bacteria growth on culture media. Finally, as mentioned, there is no standardized initial antibiotherapy regimen in place for SPE.

In conclusion, SPE is a serious disease with high morbidity and mortality rates. It could lead to invasive examinations and prolonged hospital stays if not kept in mind as possible diagnosis. In presence of bilateral peripheral nodular opacities on chest radiograms, thoracic CT that demonstrates feeding vessel sign, and baseline conditions suggesting infection, such as fever, high sedimentation rates, increased CRP level, and leukocytosis, focus (foci) of primary infection should be examined and suitable antibiotherapy should be initiated.
Conflict of interest

None declared.

\section{REFERENCES}

1. Cook RJ, Ashton RW, Aughenbaugh GL, Ryu JH. Septic pulmonary embolism: presenting features and clinical course of 14 patients. Chest 2005;128:162-6.

2. Wong KS, Lin TY, Huang YC, Hsia SH, Yang PH, Chu SM. Clinical and radiographic spectrum of septic pulmonary embolism. Arch Dis Child 2002;87:312-5.

3. King MB, Harmon KR. Unusual forms of pulmonary embolism. Clin Chest Med 1994;15:561-80.

4. Rossi SE, Goodman PC, Franquet T. Nonthrombotic pulmonary emboli. AJR Am J Roentgenol 2000;174:1499508.

5. Özlü T, Metintaş M, Karadağ M, Kaya A. Solunum sistemi ve hastalıklar1. 1. bask1. İstanbul: İstanbul Tip Kitabevi; 2010 .

6. Kuhlman JE, Fishman EK, Teigen C. Pulmonary septic emboli: diagnosis with CT. Radiology 1990;174:211-3.

7. Doğan C, Şener SŞ, Kıral N, Torun E, Salepçi B, Çağlayan B. Septic Pulmonary Embolism Secondary to Tooth Extraction. J Kartal TR 2011;22:79-83.

8. Fred HL, Harle TS. Septic pulmonary embolism. Dis Chest 1969;55:483-6.

9. Shiota Y, Arikita H, Horita N, Hiyama J, Ono T, Ohkawa $\mathrm{S}$, et al. Septic pulmonary embolism associated with periodontal disease: reports of two cases and review of the literature. Chest 2002;121:652-4.

10. Akpınar S, Uçar N, Öztürk S, Şerifoğlu İ, Yıldız M, Şipit T. A Case of Septic Pulmonary Embolism. Causapedia 2014;3:559-63.

11. Iwasaki Y, Nagata K, Nakanishi M, Natuhara A, Harada $\mathrm{H}$, Kubota Y, et al. Spiral CT findings in septic pulmonary emboli. Eur J Radiol 2001;37:190-4.

12. Jorens PG, Van Marck E, Snoeckx A, Parizel PM. Nonthrombotic pulmonary embolism. Eur Respir J 2009;34:452-74.

13. Pena E, Dennie C, Franquet T, Milroy C. Nonthrombotic pulmonary embolism: a radiological perspective. Semin Ultrasound CT MR 2012;33:522-34.

14. MacMillan JC, Milstein SH, Samson PC. Clinical spectrum of septic pulmonary embolism and infarction. J Thorac Cardiovasc Surg 1978;75:670-9.

15. Ye R, Zhao L, Wang C, Wu C, Yan H. Clinical characteristic of septic pulmonary embolism in adults: A systematic review. Respiratory Medicine 2014;108:1-8. 


\section{Pulmoner Septik Emboli Tanılı Olgularımızın Özellikleri}

Amaç: Bu çalışmada, nadir görülen, morbidite ve mortalitesi yüksek seyredebilen bir hastalık olan septik pulmoner embolinin (SPE) klinik, radyolojik ve laboratuvar özellikleri araştırıldı.

Gereç ve Yöntem: Ocak 20II-Aralık 2015 tarihleri arasında SPE ön tanısı ile incelenen ve tedavi edilen ve final tanıSı olarak SPE olan olguların dosyaları geriye dönük olarak incelendi. Olguların demografik, radyolojik, klinik ve laboratuvar bulguları kayıt edildi.

Bulgular: Çalışmaya yaş ortalamaları 44.4 9.8 yıl olan, üçü kadın yedisi erkek toplam 10 olgu alındı. Olguların en sık tespit edilen birincil enfeksiyon odağı dört (\%40) olgu ile apseli diş çekimi idi. En sık başvuru semptomu dokuz (\%90) olguda göğüs ağrısı, en sık radyolojik bulgu sekiz (\%80) olguda iki taraflı nodüller idi. Hayatını kaybeden hasta olmadı, tüm olgular başlanan antibiyoterapilere tam klinik ve radyolojik yanıt vermiştir.

Sonuç: Radyolojik olarak iki taraflı nodülleri olan olgularda, enfeksiyon parametreleri de yüksek ise SPE ayırıcı tanıya alınmalı, primer enfeksiyon odağı sorgulanmalı ve hastalara uygun antibiyoterapi başlanmalıdır.

Anahtar Sözcükler: Pulmoner emboli; septik pulmoner emboli; diş çekimi. 